It might be inferred that the Supreme Court wished to inform the Virginia courts that the lower decision was incorrect and should not be followed, thus indirectly indicating that the Richmond court decision should have no stare decisis effect in other cases arising in the Virginia courts. But then the majority of the Supreme Court apparently decided on the merits a case they held to be moot.

\title{
IV
}

Conclusions and generalizations are necessarily difficult to make. Certainly, a universally applicable rule of disposition, as it appears the Supreme Court has developed, may lead to injustice in some instances. The decision of the Supreme Court in Harris v. Battle may represent a rigid application of the usual rule of vacation. If this is all the case represents, it nevertheless will probably be interpreted as a decision on the merits in a moot case.

The position adopted by the Supreme Court in the Munsingwear case apparently is that collateral estoppel will attach in an unreversed judgment moot on appeal. It might be argued that where the mootness issue is carried to the highest court, collateral estoppel should not attach irrespective of the mode of disposition. Because of this fear of collateral estoppel, however, judgments have since been always vacated or reversed. This may mean that merger and bar effects are not now possible in judgments moot on appeal. The rule of the Munsingwear case has led the Supreme Court further than it realized at the time. Considerations of fairness to the immediate parties should govern disposition of a moot appeal. In the absence of factors recommending reversal or vacation of the lower decree, it is suggested that all moot appeals to the Supreme Court ought to be dismissed so as to gain whatever res judicata benefits there may be. Stare decisis is not a proper subject for consideration in the selection of a method of disposition.

\section{CONSIDERATION FOR THE EMPLOYER'S PROMISE OF A VOLUNTARY PENSION PLAN}

There are two basic types of pension plan: those voluntarily adopted by the employer, and those which are the product of collective bargaining. The courts have had some analytical difficulty with voluntary plans. ${ }^{1}$ The central

\footnotetext{
"The phrase "voluntary pension plan" can be confusing. Its usual meaning is "voluntarily adopted by the employer"; however it is also used where the employee has the option of contributing or not contributing to the plan. Throughout this comment, unless otherwise indicated, "voluntary pension plan" means a plan voluntarily adopted by the employer and not a plan which is the result of collective bargaining.

It should be added that while current interest is centered on collective bargaining and executive pension plans, this comment is concerned solely with the problem of consideration for the employer's promise of a pension plan. Discussion of collective bargaining and executive pension plans is accordingly limited to occasional comments bearing on the consideration problem generally.
} 
issue is whether or not consideration can be found for the employer's promise of a pension plan, and if it can, whether the consideration is in the continuity of employment or in the employee's daily work. This comment will discuss the solutions to the consideration problem which have been adopted and then apply them to the employee's right to claim benefits before retirement, at retirement, and after retirement.

\section{I}

In a number of cases the theory developed that voluntary pension plans were mere gratuities bestowed by the employer. ${ }^{2}$ With considerable success employers sought this result by inserting in the plans express disclaimers of contractual liability ${ }^{3}$ - sometimes applicable even after the employee had retired ${ }^{4}$-and terms giving to the company-appointed administrative boards full power to determine the eligibility of claimants for pensions or to calculate the amounts of their awards. ${ }^{5}$

Although the gratuity theory would seem to give the employer the power to withhold benefits arbitrarily, ${ }^{6}$ two factors have operated to limit his freedom.

2 Consult, generally, 2 Latimer, Industrial Pension Systems, c. XIV (1932), and 42 A.T.R.
2d 461, 464-67 (1955).
${ }^{3}$ Dolan v. Heller Bros. Co., 30 N.J. Super. 440, 104 A. 2d 860 (Ch., 1954); In re Missouri
Pac. R. Co., 49 F. Supp. 405 (E.D. Mo., 1943); Menke v. Thompson, 140 F. 2d 786 (C.A. 8th, 1944).

As a matter of interpretation, some courts have refused to allow employers to exercise powers of disclaimer or divestment which have been expressed ambiguously. Schofield v. Zion's Co-op. Mercantile Institution, 85 Utah 281, 39 P. 2d 342 (1934) (option to deny payments held inapplicable after the employee had retired); cf. Psutka v. Michigan Alkali Co., 274 Mich. 318, 264 N.W. 385 (1936) (disclaimer held applicable not to death benefit in issue, but only to another feature of general benefit plan). In analogous cases of death plans, disclaimers have been expressly disregarded. Tilbert v. Eagle Lock Co., 116 Conn. 357, 165 Atl. 205 (1933) ; Mabley \& Carew Co. v. Borden, 129 Ohio St. 375, 195 N.E. 697 (1935), noted in 49 Harv. L. Rev. 148 (1935). Consult 1 Williston, Contracts $\$ 140$, at 504 n. 5 (rev. ed., 1936), and Legal Status of Private Industrial Pension Plans, 53 Harv. L. Rev. 1375,1379 (1940), the latter of which offers no logical escape from strict application of disclaimer clauses.

t Umshler v. Umshler, 332 IIl. App. 494, 76 N.E. 2d 231 (1947); Gott v. Prudential Ins. Co. of America, 212 N.C. 830, 192 S.E. 905 (1937) ; Fickling v. Pollard, 51 Ga. App. 54, 179 S.E. 582 (1935).

${ }^{5}$ Going v. Southern Mill Employees Trust, - Okla. -, 281 P. $2 d 762$ (1955); Aston v. Magnolia Petroleum Co., 241 S.W. 2d 306 (Tex. Civ. App., 1951); Twiss v. Lincoln Telephone \& Telegraph Co., 136 Neb. 788, 287 N.W. 620 (1939); Magnolia Petroleum Co. v. Butler, 86 S.W. 2d 258 (Tex. Civ. App., 1935); Burgess v. First Nat'l Bank, 219 App. Div. 361, 220 N.Y. Supp. 134 (2d Dep't, 1927) (profit-sharing plan); McNevin v. Solvay Process Co., 32 App. Div. 610, 53 N.Y. Supp. 98 (4th Dep't, 1898), aff'd 167 N.Y. 530, 60 N.E. 1115 (1901); cf. Gabrell v. Grand Lodge, Brotherhood of Railway Trainmen, 177 S.E. 918 (Ga. App., 1935) (finality of board's finding in union disability benefit). In McLemore v. Western Union Telegraph Co., 88 Ore. 228, 171 Pac. 390 (1918), the conclusiveness of the finding of the pension board was limited to the factual question of compliance by the employee with conditions of the plan.

- MacCabe v. Consolidated Edison Co. of New York, 30 N.Y.S. 2d 445 (City Ct., 1941) (adding, however, that conclusion of law does not necessarily coincide with reality). 
First, employers have realized that capricious denials of pension claims or discontinuance of payments would neither promote good will nor encourage the longevity of employment sought by the adoption of the pension plan. ${ }^{7}$ Second, although strict application of the gratuity theory would not require it, ${ }^{8}$ the courts have usually raised an obligation in the employer to administer the plan in good faith. ${ }^{9}$ For example, in the leading case of McNevin v. Solvay Process Co., ${ }^{10}$ the court held that the pension plan was:

[S]imply a promise on the part of the defendant to give to its employés a certain sum in the future, with an absolute reservation that it [might] at any time determine not to complete the gift, and, if it [did] so determine, an employe [had] no right of action to recover the sum standing to his credit on the books of the pension fund.11

${ }^{7}$ It has been suggested that denial of claims under early plans resulted from the inability of the employer to calculate the necessary sums to be set aside, and the lack of incentive to establish a sound plan in the belief that, in any event, no liability would ensue. Consult the methods of financing early plans on a "pay-as-you-go" basis or by mere balance sheet entries discussed in O'Neill, Modern Pension Plans 35-37 (1947). The same study points out that the purchase of retirement annuities, encouraged by insurance companies during the 1920 's and 1930's, decreased the financial necessity of denying liability although the employer might have retained the right to do so.

${ }^{8}$ Abbott v. International Harvester Co., 36 Erie Co. L. J. 271 (Pa., 1953) (employee allegedly induced by employer to resign by promise that forthcoming pension would not be forfeited was held not entitled to bring action for fraud against employer); Kowalski v. Aetna Life Ins. Co., 266 Mass. 255, 165 N.E. 476 (1929) (discharge due to illness effected forfeiture of employee's life insurance policy); MacCabe v. Consolidated Edison Co. of New York, 30 N.Y.S. 2d 445 (City Ct., 1941) (expected reward reduced).

${ }^{\circ}$ Board decisions have been upheld which have based denials of pensions upon failure to render continuous service. Menke v. Thompson, 140 F. 2d 786 (C.A. 8th, 1944); Dowling v. Texas \& N. O. R. Co., 80 S.W. 2d 456 (Tex. Civ. App., 1935); Magnolia Petroleum Co. v. Butler, 86 S.W. 2d 258 (Tex. Civ. App., 1935). The importance attached to continuous service supports the argument advanced page 99 infra that longevity of employment is the consideration for the employer's promise of a pension.

${ }^{10} 32$ App. Div. 610, 53 N.Y. Supp. 98 (4th Dep't, 1898), aff'd 167 N.Y. 530, 60 N.E. 1115 (1901). The majority opinion, at 32 App. Div. 612, 53 N.Y. Supp. 99, states that the pension was conceded to be a gift; the dissenting opinion, at 617,103 , states that the defendant conceded the existence of a contract. The case has occasionally been interpreted to uphold the existence of a contract. McLemore v. Western Union Telegraph Co., 88 Ore. 228, 171 Pac. 390 (1918); cf. Gearns v. Commercial Cable Co., 177 Misc. 1047, 32 N.Y.S. 2d 856 (Munic. Ct., 1942), aff'd 293 N.Y. 105, 56 N.E. 2d 67 (1944). However, the real issue was whether or not a gift had been completed by crediting the passbook of an employee who was discharged after three years of service and who alleged that his pension had been denied in bad faith. Under the plan, voluntary contributions to a fund were made solely by the employer out of profits and were held in the control of company officials who were to adjudge the validity of claims. In holding for the employer, the court explained that postponed vesting was intended to protect the recipient from attachment of his interest by creditors. Such a motive is not uncommon. Plans may stipulate that the employee's interest is not assignable or subject to attachment by creditors. Hughes v. Encyclopaedia Britannica, Inc., 199 F. 2d 295 (C.A. 7th, 1952); Umshler v. Umshler, 332 Tll. App. 494, 76 N.E. 2d 231 (1947). Compare Pritchett-Thomas Co. v. Pennebaker, 10 Tenn. App. 425 (1929) (gratuitous benefits held non-assignable), with Gilbert v. Norfolk \& W. Ry. Co., 114 W. Va. 344, 171 S.E. 814 (1933) (contractual right assignable). Consult Insulating Pension Benefits from Creditors, 3 Stanford L. Rev. 270 (1951).

${ }^{11}$ McNevin v. Solvay Process Co., 32 App. Div. 610, 613, 53 N.Y. Supp. 98, 100 (4th Dep't, 1898), aff'd 167 N.Y. 530, 60 N.E. 1115 (1901). 
But the court went on to suggest that bad faith in the administration of the plan might be alleged in equity. ${ }^{12}$ In the same spirit other courts, while stressing the voluntary nature of a pension, have held that plans were "contracts of a peculiar nature."13

Another view of voluntary pension plans is that they create contractual rights in the employee. Two theories ${ }^{14}$ have been advanced as to the consideration for the employer's promise of a pension: (1) that consideration is in the longevity of service which is not assured to the employer in the normal employment contract, ${ }^{15}$ and (2) that consideration is in the daily work of the

${ }^{12} \mathrm{~A}$ reserve fund created only as a bookkeeping device as in the McNevin case, has been held not to establish a trust. Gearns v. Commercial Cable Co., 293 N.Y. 105, 56 N.E. 2 d 67 (1944). Although one New York case suggested in dictum that credits to a passbook, if accompanied by a specific fund set aside for payment of pensions, might constitute a completed gift (Dolge v. Dolge, 70 App. Div. 517, 75 N.Y.Supp.386 [4th Dep't, 1902]), it should also be noted that the disposition of a voluntary fund might be discretionary with the administrators. Burgess v. First Nat'I Bank, 219 App. Div. 361, 220 N.Y. Supp. 134 (2d Dep't, 1927); cf. Kloman v. Doctors Hospital, Inc., 76 A. 2d 782 (Munic. Ct. D.C., 1950) (surgical benefits under disability plan); Twiss v. Lincoln Telephone \& Telegraph Co., 136 Neb. 788, 287 N.W. 620 (1939). However, the administrator or trustee must perform his duties in good faith. Cf. Forrish v. Kennedy, 377 Pa. 370, 105 A. 2d 67 (1954) (employer contributions to trust under union plan); Bednar v. United Mine Workers Welfare and Retirement Fund, 25 CCH Lab. Cas. \68, 352 (D. D.C., 1953) (union pension).

Once a trust has been established, the employer frequently surrenders control over the payment of pension so that the trustee becomes defendant in actions by employees. Askinas v. Westinghouse Electric Corp., 330 Mass. 103, 111 N.E. 2d 740 (1953); cf. Legg v. Swift \& Co., 167 Mo. App. 427, 151 S.W. 230 (1912) (trust res held by third persons and contributed to only by employees, yet held in custody of employer).

In some circumstances, however, the employer may retain an interest in a revocable trust and will be a proper party in actions determining its disposition. Whitley v. Mammoth Life and Accident Ins. Co., - Ky. - 273 S.W. 2d 42 (1954) (rules of pension never adopted); Walters v. Pittsburgh \& Lake Angeline Iron Co., 201 Mich. 379, 167 N.W. 834 (1918) (dissolution of employer firm).

${ }^{23}$ Cf. Clark v. New England Telephone \& Telegraph Co., 229 Mass. 1, 118 N.E. 348 (1918) (death plan), cited in Menke v. Thompson, 140 F. 2 d 786 (C.A. 8th, 1944) (pension); Aston v. Magnolia Petroleum Co., 241 S.W. 2d 306 (Tex. Civ. App., 1951).

${ }^{16}$ A third ground for the employee's recovery would be an application of the doctrine of promissory estoppel based upon the employee's reliance on the pension to his detriment in not seeking employment elsewhere. Two California opinions have suggested that promissory estoppel might have served as an alternative ground for holding the employer liable. West v. Hunt Foods, Inc., 101 Cal. App. 2d 597, 225 P. $2 d 978$ (1951). Hunter v. Sparling, 87 Cal. App. 2d 711, 197 P. 2d 807 (1948). Consult Promissory Estoppel in California, 5 Stanford L. Rev. 783, 789 (1953).

The doctrine of promissory estoppel would be of major importance in determining the employee's rights if the corresponding benefits to the employer are considered not bargained for in the adoption of a pension plan. However, in light of the employer's purposes discussed page 100 infra, in adopting a pension, it appears simpler to enforce the promise of the pension as a contract supported by consideration. In a specific case an employee might suffer an unbargained for detriment, but generally the likelihood that he would have accepted more lucrative employment elsewhere would be more difficult to prove than would the general purpose of the employer in adopting a pension plan.

${ }^{15} \mathrm{~A}$ hiring indefinite as to time is terminable at the will of either party and therefore creates no executory obligations. 1 Williston, Contracts $\$ 39$, at 104 (rev, ed., 1936). Consult the same work at $\S 65$ for a discussion of performance as an acceptance of an offer for a uni- 
employee thus making the pension a deferred wage ${ }^{16}$ with each employee's claim subject to forfeiture if he fails to work until retirement age. If a court follows the contract approach the distinction between the two theories of consideration is immaterial either upon the retirement or after the retirement of the employee, although the two theories of consideration would lead to different results in the pre-retirement period.

Courts have often followed the first consideration theory holding that a pension plan constituted an offer to enter a unilateral contract, the acceptance of which was the completion by the employee of the requisite term of service. ${ }^{17}$ This analysis emphasizes the idea that the major objective of the employer in adopting the pension plan is to encourage continuity of employment. ${ }^{18}$

lateral contract. For an extreme position, see Ulmann v. Sunset-McKee Co., 221 F. 2d 128 (C.A. 9th, 1955), holding as an alternative ground for the employee's recovery that working for three additional days constituted consideration for the employer's promise of a pension.

${ }^{16}$ Hunter v. Sparling, 87 Cal. App. 2d 711, 197 P. $2 d 807$ (1948). See Inland Steel Co. v. NLRB, 170 F. 2d 247 (C.A. 7th, 1948), cert. denied 336 U.S. 960 (1949). Consult O'Neill, Modern Pension Plans 8-12 (1947), for a discussion of whether employer, employee, or consumer bears the cost of the plan, or whether costs are equalized between employer and employee.

${ }^{17}$ Sigman v. Rudolph Wurlitzer Co., 57 Ohio App. 4, 11 N.E. 2 d 878 (1937); Wilson v. Rudolph Wurlitzer Co., 48 Ohio App. 450, 194 N.E. 441 (1934) ; Gilbert v. Norfolk \& W. Ry. Co., 114 W. Va. 344, 177 S.E. 814 (1933); cf. Texas \& N. O. Ry. Co. v. Jones, 103 S.W. 2d 1043 (Tex. Civ. App., 1937) (plan gratuitous until fully performed, at which time it becomes binding on employer). See Gearns v. Commercial Cable Co., 177 Misc. 1047, 32 N.Y.S. 2d 856 (Munic. Ct., 1942), aff'd 266 App. Div. 315, 42 N.Y.S. 2d 81 (1st Dep't, 1943), aff'd 293 N.Y. 105, 56 N.E. 2d 67 (1944). But cf. Bromberg v. United Cigar-Whelan Stores Corp., 19 CCE Lab. Cas. I 66, 203 (N.Y. S.Ct., 1951) (qualifying general approval of the contract theory with observation that contract which employer could change unilaterally was illusory).

Compare the approach of Professor Corbin that a bonus offered by an employer becomes irrevocable by him as soon as the employee has rendered any substantial service in the process of accepting although the employer's duty to pay is conditional upon completion of service by the employee. 1 Corbin, Contracts $\$ 153$ (1950).

${ }^{18}$ Consult Gilbert v. Norfolk \& W. Ry. Co., 114 W. Va. 344, 171 S.E. 814 (1933), noting factors which justified the adoption of a pension plan as within corporate powers. Some plans have even included preambular statements to the effect that pension and death plans are designed as rewards for the long and faithful service of the employees. Schofield v. Zion's Co-op. Mercantile Institution, 85 Utah 281, 39 P. 2d 342 (1934); cf. Tilbert v. Eagle Lock Co., 116 Conn. 357, 165 Atl. 205 (1933) (death plan); Psutka v. Michigan Alkali Co., 274 Mich. 318, 264 N.W. 385 (1936) (death plan). Note, too, the inducement intended by such a phrase as, "A rolling stone gathers no moss." Wilson v. Rudolph Wurlitzer Co., 48 Ohio App. 450, 194 N.E. 441 (1934). Consult Whitley v. Mammoth Life and Accident Ins. Co., - Ky. - , 273 S.W. 2d 42 (1954) (employer interested as third party beneficiary in trust because of advantages sought therein).

The actual reliance of employees upon future expectancies as a factor in increasing longevity in one employment is uncertain. One study suggests that employees most likely to be affected are between the ages of thirty and forty-five because younger employees are generally not influenced by benefits in the distant future and because older employees are unlikely to resign because of their diminished ability to find employment elsewhere. O'Neill, Modern Pension Plans C. I (1947). In contrast, other sources indicate that pension benefits are actively sought by several categories of employees. Labor unions, which opposed early plans in 
Some support by analogy for this unilateral contract approach can be found in the death plan and bonus cases. The death plan which applies to the active employee is similar to the pension because each program conditions benefits upon continuous service until a specific occurrence-death or the employee's reaching retirement age. ${ }^{19}$ Although some death plan cases have followed the gratuity analysis, ${ }^{20}$ others have given the dependents of deceased employees vested rights to benefits despite disclaimers similar to those found in voluntary pension plans. ${ }^{21}$ Moreover, in situations where bonuses have been predicated upon the employee's serving for a stipulated period of time, some courts have enforced the employer's promise by recognizing consideration in continuity of service. ${ }^{22}$

which employees' rights were insecure, now promote pensions as a subject of collective bargaining. Compare the early opposition of labor described in O'Neill, Modern Pension Plans $3-4$ (1947), with the observation that in 1949, welfare and pension plans were, next to wage increases, the most sought-after objectives of collective bargaining. Non-contributory Pensions as Subjects of Compulsory Collective Bargaining, 13 U. of Detroit L. J. 20, n. 1 (1949). Although this change in attitude has led to the adoption of plans with firmer rights than under voluntary plans, the change also indicates the inherent appeal of pensions. Pensions may also be a significant inducement among management trainees (The Class of ' 49,39 Fortune, no. 6, at 84 [June, 1949]) and in the higher echelons of management. One case, in upholding an executive pension plan against shareholder attack in a derivative suit, stressed that one object of the plan was to attract and retain capable leaders. The court noted that executives who may only gradually attain leading positions find it difficult to save much of their income for retirement. Holmes v. Republic Steel Corp., 69 N.E. 2d 396 (Ohio C.P., 1946).

Other advantages to the employer listed in O'Neill, Modern Pension Plans 4-6 (1947), include the retirement of superannuated employees with a minimum of hostility among personnel and throughout the community (consult, also, Pensions for Enterprise, 41 Fortune, no. 1, at 62 [Jan., 1950]); the improvement of company morale, together with a reduction or elimination of strikes and labor trouble (contrast the reaction by a union to new voluntary benefits by the employer noted in Business Roundup, The Cost of Pensions, 41 Fortune, no. 1, at 16-17 [Jan., 1950]).

${ }^{10}$ The recent pension case of Hughes v. Encyclopaedia Britannica, 1 Ill. App. 2d 514, 117 N.E. 2d 880 (1954), in rejecting the theory that a pension constitutes a unilateral contract, attempted to distinguish the death plan cases of Psutka v. Michigan Alkali Co., 274 Mich. 318, 264 N.W.385 (1936), and Tilbert v. Eagle Lock Co., 116 Conn. 357, 165 Atl. 205 (1933). Also consult Jensen v. The Bell Telephone Co. of Penna., $29 \mathrm{~Pa}$. Dist. \& Co. 476 (1937), Robinson v. Standard Oil Co. of Louisiana, 180 So. 237 (La. App., 1938), and 1 Williston, Contracts $\S 130 \mathrm{~B}$ (rev. ed., 1936).

${ }^{20}$ Aston v. Magnolia Petroleum Co., 241 S.W. 2d 306 (Tex. Civ. App., 1951) ; Webster v. Southwestern Bell Telephone Co., 153 S.W. 2d 498 (Tex. Civ. App., 1941) ; Spiner v. Western Union Telegraph Co., 73 S.W. 2d 566 (Tex. Civ. App., 1934) ; Clark v. New England Telephone \& Telegraph Co., 229 Mass. 1, 118 N.E. 348 (1918). However, the courts required the employers to act in good faith.

${ }_{2}^{2}$ Psutka v. Michigan Alkali Co., 274 Mich. 318, 264 N.W. 385 (1936); Mabley \& Carew Co, v. Borden, 129 Ohio St. 375, 195 N.E. 697 (1935), noted in 49 Harv. L. Rev. 148 (1935); but cf. Meyerson v. New Idea Hosiery Co., 21' Ala. 153, 115 So. 94 (1927), adopting a strict gratuity theory of death benefits and denying the dependent's claim without assistance from disclaimer clauses.

${ }^{2}$ Scott v. Duthie \& Co., 125 Wash. 470, 216 Pac. 853 (1923); Mickshaw v. Coca Cola Bottling Co. of Sharon, Pa., $166 \mathrm{~Pa}$. Super. 148, 70 A. 2d 467 (1950) (difference between 
The deferred wage theory of consideration for the employer's promise of a pension, advanced in some cases, ${ }^{23}$ finds additional support in cases holding that pensions are proper subjects for collective bargaining. ${ }^{24}$ For example, the court in one collective bargaining case suggested that a pension in reality constituted wages:

It surely cannot be seriously disputed but that such a pledge on the part of the company forms a part of the consideration for the work performed, and we see no reason why an employee entitled to the benefit of the plan could not upon the refusal of the company to pay, sue and recover such benefits. In this view, the pension thus promised would appear to be as much a part of his wages as the money paid to him at the time of the rendition of his services. ${ }^{25}$

Further support for this view can be found in a collective bargaining case holding that a bonus was a deferred wage. ${ }^{26}$ The court observed that it was misleading to call the bonus a "gift," if, like a pension, it was regular and so tied to the salary scale that in effect it was a part of an employee's usual compensation.

The proposition that pension benefits constitute deferred wages for ordinary services rendered may at first glance seem to disregard the factor of continuity of service, presumably the principal object of voluntary pension plans. In some instances, of course, continuity may not be the major purpose of the

military payments and wages promised if employee would stay until inducted into service); cf. Wellington v. Curran Printing Co., 216 Mo. App. 358, 268 S.W. 396 (1925) (profitsharing plan), and Willoughby Camera Stores, Inc. v. Comm'r, 125 F. 2d 607 (C.A. 2d, 1942) (income tax deductions allowed for contributions into bonus fund on basis that contractual right was created in employees); cf. Kerbaugh v. Grey, 212 Fed. 716 (C.A. 2d, 1914) (bonus to speed up lagging job). Contra: Kostenbader v. Schoeneck Farms, Inc., 134 Pa. Super. 334, 4 A. 2d 199 (1939) (promise of bonus held to be at most the prospect of a gratuity and did not imply the existence of a contract for a definite period of time). The reward bonus must be contrasted with that which becomes a regular part of the employee's remuneration. E.g., NLRB v. Niles-Bement-Pond Co., 199 F. 2 d 713 (C.A. 2d, 1952) (Christmas bonus).

${ }^{23}$ E.g., Hunter v. Sparling, 87 Cal. App. 2d 711, 197 P. $2 d 807$ (1948). Cf. 1 Corbin, Contracts $\$ 153$, at 502 n. 12 (1950).

${ }^{24}$ Consult Non-Contributory Pensions as Subjects of Collective Bargaining, 13 U. of Detroit L. J. 20 (1949).

${ }^{2}$ Inland Steel Co. v. NLRB, 170 F. 2d 247, 253 (C.A. 7th, 1948), cert. denied 336 U.S. 960 (1949). However, the decision was strictly based upon the view that pensions constitute "conditions of employment" under the provision of the Taft-Hartley Act requiring employers to bargain "in respect to rates of pay, wages, hours of employment, or other conditions of employment." 61 Stat. 140, 143 (1947), 29 U.S.C.A. $\$ \$ 158(a)(5), 159$ (a) (Supp., 1954) ; cf. NLRB v. Jacobs Manufacturing Co., 196 F. 2d 680 (C.A. 2d, 1952). It is important that the court in the Inland Steel case was referring to the voluntary pension plan which had been in operation before the decision and not a collective bargaining agreement which would clearly have vested contractual rights in the employee.

${ }^{29}$ NLRB v. Niles-Bement-Pond Co., 199 F. 2d 713, 714 (C.A. 2d, 1952). Cf. NLRB v. Century Cement Manufacturing Co., 208 F. 2d 84 (C.A. 2d, 1953); Carlisle \& Jacquelin, 55 N.L.R.B. 78 (1944) (profit-sharing plan); Singer Manufacturing Co. v. NLRB, 119 F. 2d 131 (C.A. 7th, 1941). Contributions to health plans may also be treated as wages. Potlatch Forests, Inc. v. International Woodworkers of America, 108 F. Supp. 906 (N.D. Idaho, 1951). 
plan. ${ }^{27}$ Executive pensions designed to allocate income over an extended period of years for tax purposes seem to be examples of deferred wages. ${ }^{28}$ Even assuming that the sole purpose of the voluntary plan is to encourage longevity of employment, the deferred wage theory is consistent with that object insofar as the threat of losing the accumulated benefits may serve to discourage employees from leaving before retirement age. Thus, the employee's failure to remain for the requisite period may be treated as forfeiting the pension element in his wage. ${ }^{29}$

The difference between the two theories of consideration is apparently only one of viewpoint. Regarded positively, the pension is a reward for long and faithful service; negatively, it is in the nature of a penalty for leaving the employer before reaching retirement age. The difference in legal result comes as a result of the different time of vesting under the two theories: by the unilateral contract theory the employee has no rights until he has worked until retirement age, ${ }^{30}$ whereas under the deferred wage analysis the employee's rights vest as soon as he earns the amount contributed or set aside for his benefit.

II

The remainder of this comment will examine the rights of the employee upon application of the gratuity, unilateral contract, and deferred wage theories; first upon and after retirement, and second, before retirement.

\section{At Retirement and after Retirement}

Under the gratuity theory no claim vests in the employee until the amount of his pension has been determined and payment has been made, thus com-

${ }^{27}$ Where plans provide for eligibility to retire on pension long before the employee may wish to retire, longevity is not an objective, and the deferred wage theory becomes most plausible. Hunter v. Sparling, 87 Cal. App. 2d 711, 197 P. 2d 807 (1948) (pension payable after only ten years while employee worked for forty-nine years).

${ }^{28}$ Holmes v. Republic Steel Corp., 69 N.E. 2d 396, 410 (Ohio C.P., 1946), judgment modified on another issue 84 N.E. 2d 508 (Ohio App., 1948). Consult Incentive Compensation Plans, 39 Fortune, no. 5, at 143 (May, 1949), for a discussion of the problems involved in attempting to secure tax advantages to executives by payments of large pensions.

It may be noted that in collective bargaining plans the union is probably most interested in the forced savings character of pensions as an aid to employees who lack the financial foresight to prepare for their old age. Inland Steel Co., 77 N.L.R.B. 1, 5 (1948), aff'd 170 F. 2d 247 (C.A. 7th, 1948), cert. denied 336 U.S. 960 (1949) ; Non-contributory Pensions as Subjects of Compulsory Collective Bargaining, 13 U. of Detroit L. J. 20, 23-24 (1949). Consult O'Neill, Modern Pension Plans 17-20 (1947), for a discussion of the difficulty of accumulating large savings because of high taxes and low interest rates on investments.

${ }^{2}$ Cf. Jacobus v. Massachusetts Mut. Life Ins. Co., 91 F. Supp. 674 (W.D. N.Y., 1950) (deferred wage theory applied to pension which could be forfeited upon discharge for moral turpitude or voluntary resignation to work for competitor).

${ }^{30}$ Professor Corbin would dissent from this view, suggesting that whenever the employee had done any substantial amount of work he should be considered as having accepted the employer's unilateral offer of a pension plan thus gaining vested rights in the pension plan as he works. 1 Corbin, Contracts $\$ 153$ (1950). This variation of the unilateral contract theory leads to the same results as the deferred wage analysis and is discussed infra page 107 . 
pleting the gift by delivery. ${ }^{31}$ Where the payments are periodic until death, the employer may either terminate or reduce the payments which have already begun, ${ }^{32}$ and similarly at the point of retirement the employer can either reduce anticipated payments ${ }^{33}$ or reject an employee's claim upon application for retirement benefits. ${ }^{34}$

Application of either the unilateral contract theory or the deferred wage analysis would lead to results precisely opposite to those under the gratuity theory. Under neither theory could payments be denied or reduced at retirement, ${ }^{35}$ or, after retirement, be reduced or terminated. ${ }^{36}$ This follows because

"r Korb v. Brooklyn Edison Co., 258 App. Div. 799, 15 N.Y.S. 2d 557 (2d Dep't, 1939).

${ }^{32}$ Umshler v. Umshler, 332 Ill. App. 494, 76 N.E. 2d 231 (1947); In re Missouri Pac. R. Co., 49 F. Supp. 405 (E.D. Mo., 1943) ; Fickling v. Pollard, 51 Ga. App. 54, 179 S.E. 582 (1935) ; cf. Gott v. Prudential Ins. Co. of America, 212 N.C. 830,192 S.E. 905 (1937) (disability benefits). One case, however, held that although a pension plan is gratuitous until the employee completed his service, it then became binding and payment could not be suspended. Texas \& N. O. R. Co. v. Jones, 103 S.W. 2d 1043 (Tex. Civ. App., 1937).

${ }^{33}$ Korb v. Brooklyn Edison Co., 258 App. Div. 799, 15 N.Y. Supp. 2d 557 (2d Dep't, 1939).

${ }^{34}$ Cf. Bromberg v. United Cigar-Whelan Stores Corp., 19 CCH Lab. Cas. ๆ 66, 203 (N.Y. S.Ct., 1951) (indicating preference for unilateral contract theory in disability pension problem, but noting that any contract would be illusory in light of employer's power to modify plan unilaterally). As indicated earlier, administrative boards have, in effect, been required to act in good faith, and the gratuity theory at the point of retirement has often been modified to recognize some obligation. See cases cited note 9 supra.

${ }^{35}$ E.g., Wilson v. Rudolph Wurlitzer Co., 48 Ohio App. 450, 194 N.E. 441 (1934) (unilateral contract). Moore v. Postal-Telegraph Cable Co., 202 S.C. 225, 24 S.E. 2d 361 (1943) (death plan) (deferred wage).

${ }^{36}$ Under the unilateral contract heading, see Ulmann v. Sunset-McKee Co., 221 F. 2d 128 (C.A. 9th, 1955) (one ground of opinion that working for three days after offer of pension constituted consideration) ; Gilbert v. Norfolk \& W. Ry. Co., 114 W. Va. 344, 171 S.E. 814 (1933) (enforceable against trustee in bankruptcy); cf. Gearns v. Commercial Cable Co., 177 Misc. 1047, 32 N.Y.S. 2d 856 (Munic. Ct., 1942), aff'd 266 App. Div. 315, 42 N.Y.S. 2d 81 (1st Dep't, 1943), aff'd 293 N.Y. 105, 56 N.E. 2d 67 (1944) (contract existed although payments suspendable because to be made only out of profits, which did not exist). Consult also, 1 Williston, Contracts $\$ 13$ (rev. ed., 1936).

Under the deferred wage heading, see Hunter v. Sparling, 87 Cal. App. 2d 711, 197 P. 2d 807 (1948) ; David v. Veitscher Magnesitwerke Actien Gesellschaft, 348 Pa. 335, 35 A. 2d 346 (1944); In re Schenectady Ry. Co., 93 F. Supp. 67 (N.D. N.Y., 1950) (enforceable against trustee in bankruptcy) ; cf. Vallejo v. American R. Co. of Porto Rico, 188 F. 2d 513 (C.A. 5 th, 1951) (contractual right under collective bargaining plan).

On the other hand, the pensioner should not be entitled to an increase later provided by the employer. Sessions v. Southern California Edison Co., 47 Cal. App. 2d 611, 118 P. 2d 935 (1941).

Regarding powers of suspension, absent express provision therefor, a distinction should be made between promises to employees already superannuated to pay benefits for the remainder of their lives and the prior adoption of a plan upon which the employees could reasonably have relied in continuing employment. In the former situation no wage would be earned under the deferred wage theory. Under the unilateral contract theory, no consideration would ordinarily exist despite the presence of a moral obligation, and payments could be discontinued. Plowman v. Superior Steel Corp., 20 F. Supp. 11 (E.D. Ill., 1937) ; Shear Co. v. Harrington, 266 S.W. 554 (Tex. Civ. App., 1924). Contra: Grady v. Appalachian Electric Power Co., 126 W. Va. 546, 29 S.E. 2d 878 (1944) (disability pension promised after employee became disabled). An exception exists when benefits are conditioned upon for- 
under the unilateral contract theory the employee has completed his performance, thus accepting the offer, and under the deferred wage theory he has earned his full wage without having forfeited any portion by voluntary act.

The importance of the distinction between the gratuity and contract theories has been minimized at retirement and after retirement by the popularity of funded plans affording tax benefits only to the employer whose program vests rights irrevocably in the employee who works until retirement age. ${ }^{37}$ Deductions for payments made to pension funds are now available only if the contributions are irrevocable. ${ }^{38}$ Thus, where a tax qualified pension plan has been adopted, the rights of an employee once he has reached retirement age cannot be terminated even though the plan as a whole is considered gratuitous. ${ }^{39}$

\section{Before Retirement}

The rights of the employee are most insecure before he reaches retirement age and it is in this period that the choice of theory becomes crucial. There are two major problem areas: first, where the employer attempts to suspend or amend the plan, and second, where the employment relationship is terminated.

\section{a. Suspension or Amendment}

In Hughes v. Encyclopaedia Britannica, Inc., ${ }^{40}$ the employer sought to discontinue a pension plan which provided for the purchase of retirement annuities. The plan was expressly voluntary and the existence of a contract of employment providing for either the payment of pension or for a definite term of employment was also in terms denied. There was a further provision that the plan could be amended or terminated at the will of the employer, although the contributions were expressly made irrevocable. The court held that the employees could not compel the employer to continue purchasing annuities under the plan and denied the existence of a contract upon the

\footnotetext{
bearance by the pensioner from such actions as revealing company secrets or acting to the prejudice of the employer (Specht v. Eastwood-Neally Corp., 34 N.J. Super. 156, 111 A. 2d 781 [1955] [breach by former employee justified suspension of payments]); or obtaining employment elsewhere if such forbearance constitutes an advantage to the employer (Langer v. Superior Steel Corp., $105 \mathrm{~Pa}$. Super. 579, $161 \mathrm{Atl}$. 571 [1932]). The Langer case gave as an alternative ground for recovery promissory estoppel based upon the detrimental reliance of the employee after retirement. Also consult Rest., Contracts $\$ 90$ (1936).

${ }^{57}$ Consult, generally, O'Neill, Modern Pension PIans c. II (1947).

${ }^{38}$ Int. Rev. Code $\$ 401$ (1954), 26 U.S.C.A. $\$ 401$ (1955). 2 CCH 1955 Fed. Tax Rep. \$1 2609.

${ }^{30}$ See Hughes v. Encyclopaedia Britannica, 1 III. App. 2d 514, 117 N.E. 2d 880 (1954).

${ }^{40} 1$ IIl. App. 2d 514, 117 N.E. 2d 880 (1954). The United States Court of Appeals had previously dismissed the case for want of jurisdiction, but had expressed an opinion on the merits similar to that of the Illinois court. 199 F. 2d 295 (C.A. 7th, 1952).
} 
gratuity theory. ${ }^{41}$ It was added in dictum that even if there were a contract, the term authorizing suspension would have been binding on the employee.

The unilateral contract theory would produce the same result because the employer would be free to revoke the offer until it has been accepted by service until retirement age. ${ }^{42}$ Under the deferred wage theory, however, the employee would be entitled at least to a pro rata share of the pension fund. ${ }^{43}$

Whatever theory of pension is applied, the suspension and amendment problems are now frequently alleviated in part, as in the Hughes case, by the adoption of tax qualified plans vesting employees' rights irrevocably in funds or annuity policies to the extent of contributions already made. However, even under a tax qualified plan, application of none of the theories would require the employer to make further contributions under the plan. ${ }^{44}$

\section{b. Termination of the Employment Relation}

Pension plans often provide that they create no right in employees to be retained until retirement age ${ }^{45}$ and may even expressly deny the validity of

12 The similar problem of a reduction in coverage of a plan arose in Dolan v. Heller Brothers Company, 30 N.J. Super. 440, 104 A. 2d 860 (Ch., 1954), wherein an employee who had already reached the retirement age when the plan was adopted was barred from participation by a retroactive amendment. The court appeared to base its denial of a pension claim upon the theory that the plan was a gratuity in which an employee could have no vested right until payments were received. To the argument that the long and faithful service of the employee constituted consideration for the promise of a pension, the court observed that the employee was over the retirement age when the plan was adopted and had not acted in reliance thereon. Although the dictum implies that a plan might not be amended retroactively if a contract exists, under a strict unilateral contract theory the offer might be revoked.

${ }^{8}$ Wallace v. Northern Ohio Traction \& Light Co., 57 Ohio App. 203, 13 N.E. 2d 139 (1937) (plan abandoned and employee discharged before retirement age) ; cf. Stein v. Nat'l Bank of Commerce, 181 S.W. 1072 (Mo. App., 1916) (abandonment not contested, but employee otherwise becoming eligible between resolution of abandonment and date of final payment into fund held barred). Consult generally, I Williston, Contracts $\$ 60$ (rev. ed., 1936).

4s In Kern v. Long Beach, 29 Cal. $2 d$ 848, 179 P. 2d 799 (1947) the deferred wage theory was applied to allow recovery of a public pension repealed before retirement age, the court holding the denial unconstitutional. The general applicability of the deferred wage theory to private pensions is indicated by the reliance on the Kern case in Hunter v. Sparling, 87 Cal. App. 2d 711, 197 P. 2d 807 (1948), allowing recovery to a retired employee whose payments had been suspended.

"Hughes v. Encyclopaedia Britannica, Inc., 199 F. 2d 295 (C.A. 7th, 1952), 1 IIl. App. 2d 514, 117 N.E. 2d 880 (1954); cf. Cowles v. Morris \& Co., 330 III. 11, 161 N.E. 150 (1928), wherein a contract recognized between the employer and employee did not preclude discontinuance of the plan upon merger with another company (no tax deduction alleged).

An exception is the case of the collective bargaining agreement which is to endure for a specific period during which both parties agree not to change or request a change in the plan. Consult Pension and Group Insurance Agreement between Inland Steel Company and United Steelworkers of America 7, 10-11 (July 1, 1954).

${ }^{25}$ Hughes v. Encyclopaedia Britannica, Inc., 199 F. 2d 295 (C.A. 7th, 1952), 1 IIl. App. 2d 514, 117 N.E. 2d 880 (1954) (but allowing pro-rata allowances upon termination after varying periods of employment).

Such a term is simply a restatement of the common-law rule that the normal employment 
claims if employment is terminated before retirement. ${ }^{46}$ These terms achieve the same result as the gratuity theory and the unilateral contract theory as usually applied. Under the gratuity theory the employer would be under no compulsion to complete his gift, ${ }^{47}$ and under the unilateral contract theory the employer may revoke the offer of a pension at any time before performance is completed by service until retirement age. ${ }^{48}$

A variation of the unilateral contract theory is illustrated by the case of Roberts v. Mays Mills, ${ }^{49}$ the reasoning of which is supported by Professor Corbin. ${ }^{50}$ An employee, hired for an indefinite period and wrongfully discharged, was allowed to recover a pro-rata share of the bonus promised him at the end of a year's work. The court explained its holding on the theory that the employee accepted the unilateral offer of the bonus, not upon completion of the year's service, but upon beginning work. The limitation of the employee's recovery to a pro-rata share was justified on the basis that employment was for an indefinite period and could be terminated at will. ${ }^{51}$

contract endures for an indefinite period and is terminable at the will of either party. Consult 1 Williston, Contracts $\$ 39$, at 106 (rev. ed., 1936). See Askinas v. Westinghouse Electric Corp., 330 Mass. 103, 111 N.E. 2d 740 (1953), and Sabl v. Laenderbank Wien Aktiengesellschaft, 30 N.Y.S. 2d 608 (S. Ct., 1941), modified on other issues 33 N.Y.S. 2d 764 (S. Ct., 1942), for rejections of the notion that a pension creates a contract of employment for a fixed duration; cf. Gelhaus v. Eastern Air Lines, Inc., I94 F. 2d 772 (C.A. 5th, 1952).

"Bos v. United States Rubber Co., 100 Cal. App. 2d 565, 224 P. 2d 386 (1950) ; Umshler v. Umshler, 332 III. App. 494, 76 N.E. 2d 231 (1947); Schofield v. Zion's Co-op. Mercantile Institution, 85 Utah 281, 39 P. 2d 342 (1934). Compare Western Electric Co., Plan for Employees' Pensions, Disability Benefits and Death Benefits (1953) $\$ 8(1)$, specifying no claim upon discharge unless right to pension has previously accrued.

${ }^{47}$ Kowalski v. Aetna Life Ins. Co., 266 Mass. 255, 165 N.E. 476 (1929) (termination because of sickness) ; Burgess v. First Nat'l Bank, 219 App. Div. 361, 220 N.Y. Supp. 134 (2d Dep't, 1927) (share in profit-sharing plan denied upon discharge).

The theory was applied in the analogous situation of an employer who represented to his employee of thirty-seven years that if the latter resigned he would not lose his health and old age benefits. In an action by the employee for fraud and deceitful breach of contract, the court reasoned that since the employee could be discharged without cause, he could also be induced to retire under any representation. Abbott v. International Harvester Co., 36 Erie Co. L. J. 271 (Pa., 1953); see, also, MacCabe v. Consolidated Edison Co. of New York, 30 N.Y.S. 2d 445 (City Ct., 1941).

${ }^{4}$ Bos v. United States Rubber Co., 100 Cal. App. 2d 565, 224 P. 2d 386 (1950); Wallace v. Northern Ohio Traction \& Light Co., 57 Ohio App. 203, 13 N.E. 2d 139 (1937); Harding v. Montgomery Ward Co., 58 N.E. 2d 75 (Ohio App., 1944) (bonus). But cf. Vallejo v. American R. Co. of Porto Rico, 188 F. 2d 513 (C.A. 5th, 1951) (employees eligible for collective bargaining pension could not be discharged without liability).

${ }^{40} 184$ N.C. 406 , 114 S.E. 530 (1922), 28 A.L.R. 338 (1924); cf. Zwolaneck v. Baker Mfg. Co., 150 Wis. 517, 137 N.W. 769 (1912) (offer under profit-sharing plan accepted upon performance of substantial amount of work). Consult 4 Williston, Contracts $\$ 1028$ (rev. ed., 1936).

${ }^{50} 1$ Corbin, Contracts $\$ 153$ (1950).

W Contrast the situation wherein the employee hired for a definite duration may recover 
The result of the Roberts case might be more easily explained by use of the deferred wage analysis ${ }^{52}$ under which the rights of an employee would vary according to the circumstances of the termination of the employment relationship. The several reasons for ending the employment contract can be arranged in a continuum running from discharge in bad faith for the sole purpose of barring pension claims, to voluntary resignation by the employee.

At either extreme the application of the deferred wage is quite simple. Where there is bad faith on the part of the employer, the employee should be allowed to recover the amount of the pension which he has already earned. ${ }^{53}$ The development of the obligation of good faith in the gratuity ${ }^{54}$ and unilateral contract ${ }^{55}$ theories might well lead to the same result. It is also clear that when the employee is discharged for cause related to his services ${ }^{56}$ or

the full amount of his bonus upon wrongful discharge. Buchanan \& Son v. Ewell, 148 Va. 762, 139 S.E. 483 (1927); Gressing v. Musical Instrument Sales Co., 222 N.Y. 215, 118 N.E. 627 (1918).

E2 This pro-rata solution might also have been applied in Sabl v. Laenderbank Wien Aktiengesellschaft, 30 N.Y.S. 2d 608 (S. Ct., 1941), judgement modified on other issues 33 N.Y.S. 2d 764 (S. Ct., 1942), wherein the court refused to allow recovery of a pension by an employee who fled from Vienna during Nazi persecutions and was consequently discharged. The court held that to award a pension would in effect be to transform the employment contract into one for a fixed period for the breach of which the employer would be liable for liquidated damages in the amount of the pension. Compare the facts of The Ottoman Bank v. Chakarian, [1930] A.C. 277 , wherein an employee held to be wrongfully discharged was awarded his full pension. The theory of consideration was not given. See also, West v. Hunt Foods, Inc., 101 Cal. App. 2d 597, 225 P. 2d 978 (1951) (pro-rata bonus plus pension of undetermined sum allowed, no definite sum having been promised); Freund v. Laenderbank Wien Aktiengesellschaft, 111 N.Y.S. 2d 178 (S. Ct., 1949), aff'd 277 App. Div. 770, 97 N.Y.S. 2d 549 (1st Dep't, 1950) (pension on discharge without cause).

${ }^{23}$ Cf. Zwolaneck v. Baker Mfg. Co., 150 Wis. 517, 137 N.W. 769 (1912), in which the theory that acceptance of an offer occurs upon completion of a substantial amount of work was applied upon an employee's discharge the day before becoming eligible for claim under profit-sharing plan.

Consult McNevin v. Solvay Process Co., 32 App. Div. 610, 53 N.Y. Supp. 98 (4th Dep't, 1898), aff'd 167 N.Y. 530, 60 N.E. 1115 (1901), and cases cited note 9 supra. But cf. Abbott v. International Harvester Co., 36 Erie Co. L. J. 271 (Pa., 1953).

${ }^{55}$ Sigman v. Rudolph Wurlitzer Co., 57 Ohio App. 4, 11 N.E. $2 d 878$ (1937); Wilson v. Rudolph Wurlitzer Co., 48 Obio App. 450, 194 N.E. 441 (1934); cf. Bednar v. United Mine Workers Welfare and Retirement Fund, $25 \mathrm{CCH}$ Lab. Cas. 168, 352 (D. D.C., 1953) (denial by union fund when employee failed to work last two days before becoming eligible and was subsequently discharged by employer for old age). In Askinas v. Westinghouse Electric Corp., 330 Mass. 103, 111 N.E. 2d 740 (1953), Bos v. United States Rubber Co., 100 Cal. App. 2d 565, 224 P. 2d 386 (1950), and Wallace v. Northern Ohio Traction \& Light Co., 57 Ohio App. 203, 13 N.E. 2d 139 (1937), a general obligation to pay was recognized, but bad faith was not found in discharge. See Weiner v. Pictorial Paper Package Corp., 303 Mass. 123, 134, 20 N.E. 2d 458, 464 (1939) (discharge one month after contract for "permanent employment" was entered) for a statement justifying the obligation of good faith.

${ }^{B 8}$ Compare the similar results under the gratuity theory (Twiss v. Lincoln Telephone \& Telegraph Co., 136 Neb. 788, 287 N.W. 620 [1939]) and unilateral contract theory (Marquart v. Baltimore \& O. R. Co., 49 Ohio App. 141, 195 N.E. 396 [1934]) (discharge for insubordination although employee had requisite service for pension). 
when he voluntarily resigns, ${ }^{57}$ he is not entitled to a pension claim under the deferred wage theory because in both situations the employee has either directly or in the form of inadequate service terminated his employment and voluntarily forfeited his pension earned..$^{58}$

The question is considerably closer in the middle situations wherein neither party can be said to have acted voluntarily. Where the employee is discharged for cause unrelated to his services, but not for purpose of denying him a pension, he should probably be able to recover a pro-rata share ${ }^{59}$ even though his discharge may be to the advantage of the employer as in cases of discharge for cause. ${ }^{60}$ He should more clearly be allowed to recover a proportionate share when he is dismissed for good business reasons unrelated to the quality of his services. ${ }^{61} \mathrm{He}$ has earned part of his promised pension, and presumably was prepared to work until retirement age and he should, therefore, be entitled to recover his total earned wage. Similarly, where the employee is forced to resign because of disability or death, it seems harsh to hold that he or his estate should suffer a forfeiture because he did not complete his term of services. ${ }^{62}$ In practical effect, this final problem may be somewhat academic insofar as employee benefit plans often include provisions for disability or death payments as well as for pensions. ${ }^{63}$

${ }^{87}$ Jacobus v. Massachusetts Mut. Life Ins. Co., 91 F. Supp. 674 (W.D. N.Y., 1950); Accord: Going v. Southern Mill Employees' Trust, - Okla. -, 281 P. 2d 762 (1955) (gratuity theory applied to disability pension).

${ }^{58}$ Contrast the provisions of the recent collective bargaining agreements between the United Automobile Workers and the Ford Motor Company and General Motors Company. Union workers participating in the pension programs are granted vested rights when they reach the age of forty after only ten years' service. Such rights entitle them to pensions at the age of sixty-five even though they may no longer be employed by the companies at that time. N.Y. Times, p. 22, col. 3 (June 18, 1955).

${ }^{50}$ Cf. Roberts v. Mays Mills, 184 N.C. 406,114 S.E. 530 (1922), 28 A.L.R. 338 (1924), applying theory that bonus offer was accepted upon beginning work to situation of discharge because of personal quarrel with superior.

${ }^{\infty}$ Compare Markus v. Boston Edison Co., 317 Mass. 1, 56 N.E. 2d 910 (1944), in which the employee was discharged after conviction of a crime. He was to have been paid a retirement stipend if discharged for reasons not his own fault, but was denied his pension, instead, upon breach of continuous service for the "substantial period" of a single day elapsing before his discharge. Cf. Thayre v. London, Brighton, and South Coast Ry. Co., 22 T.I.R. 240 (K.B., 1906) (discharge for dishonesty as forfeiture under plan held to include dishonesty in private life).

" Contrast the effect of the unilateral contract theory. Wallace v. Northern Ohio Traction \& Light Co., 57 Ohio App. 203, 13 N.E. 2d 139 (1937) (curtailment of activities).

${ }^{62}$ Recovery would be denied under the gratuity theory, Kowalski v. Aetna Life Ins. Co., 266 Mass. 255, 167 N.E. 476 (1929) (siclness) ; and under the unilateral contract theory, Olson v. Republic Metals \& Roofing Materials, Inc., 347 IIl. App. 422 (1952) (individual contract with employee who died before retirement), and O'Brien v. Tremaine, 285 N.Y. 233, 33 N.E. 2d 536 (1941) (death between application for statutory retirement benefits and actual retirement).

${ }^{\infty}$ E.g., O'Brien v. Tremaine, 285 N.Y. 233, 33 N.E. 2d 536 (1941) (widow denied pension claim but granted lower death benefit); Western Electric Co., Plan for Employees' Pensions, Disability Benefits and Death Benefits $\$ 6$ (1953) (eligibility for limited benefits after only two years' service). 
Assuming that the deferred wage analysis is adopted, further difficulty may be encountered in the pre-retirement period by terms in the pension plan purporting to deny liability to employees who do not work until retirement age. If faced with such a term courts might well follow the solution suggested by cases which have allowed recovery at retirement and after retirement by interpreting disclaimers expressed ambiguously in favor of the employee. ${ }^{64}$ Thus, if the term does not specifically refer to wrongful discharge, ${ }^{65}$ it may be regarded as ambiguous and should be construed against the employer to allow recovery by the employee whenever he is dismissed for causes beyond his control. On the other hand, if the pension plan specifically provides that an employee under no circumstances shall be entitled to pension benefits if he fails to complete his term of service, ${ }^{66}$ then the courts will be forced either to abandon the deferred wage theory as being practically indistinguishable from the unilateral contract theory, or to strike the term down. The latter could perhaps be justified on the theory that it was an unconscionable imposition on the employee, in light of the inequality of bargaining power between employer and employee, to deprive the employee of his full earned wage when he is dismissed without fault on his part. ${ }^{67}$

${ }^{a}$ Schofield v. Zion's Co-op. Mercantile Institution, 85 Utah 281, 39 P. 2d 342 (1934); cf. Psutka v. Michigan Alkali Co., 274 Mich. 318, 264 N.W. 385 (1936) (death plan) ; Tilbert v. Eagle Lock Co., 116 Conn. 357, 165 Atl. 205 (1933) (death plan) ; Mabley \& Carew Co. v. Borden, 129 Ohio St. 375, 195 N.E. 697 (1935) (death plan). An extreme application of this solution was made in an action by an employer to recover a pre-paid bonus from a salesman who had resigned, thereby effecting a forfeiture under an oral contract with the employer. The court held that in absence of an unequivocal provision, the employee would not be held to forfeit the earned portion of his bonus. United Shoe Co. v. Dryer, 16 La. App. 605, 135 So. 50 (1931).

This result may be supported by applying the rule that the words of the pension contract should be taken most strongly against the employer who wrote it. Western Union Telegraph Co. v. Hughes, 228 Fed. 885, 886-87 (C.A. 4th, 1915); cf. Kline v. Morrison, 353 Pa. 79, 44 A. 2d 267 (1945), and Dom v. State Employes Retirement Fund, 345 Pa. 489, 28 A. 2 d 796 (1942) (both cases of public benefit funds).

es c[ $T$ T $]$ he Institution expressly reserves its right and privilege to discharge at any time any officer or employee when the interest of the Institution in its judgment may so require, without liability for any claim for pension or other allowance than wages due and unpaid." Schofield v. Zion's Co-op. Mercantile Institution, 85 Utah 281, 284, 39 P. 2d 342, 343 (1934). Application of the deferred wage theory to the express denial of pension liability would mean merely that the employee could not claim a full pension.

cos "[I]f the employment of a participant is terminated he may elect to have his contributions refunded to him [under contributory plan], in which event there shall be cancelled as of the date of the election all normal retirement annuity which has been purchased by such contributions, and he shall cease to be a participant under the contract." Gelhaus v. Eastern Air Lines, Inc., 194 F. 2d 772, 773 (C.A. 5th, 1952).

${ }^{07}$ Cf. Johnson v. Fargo, 98 App. Div. 436, 90 N.X. Supp. 725 (4th Dep't, 1904), aff'd 184 N.E. 388 (1906) (clause in employment contract absolving employer from liability for negligence held void as against public policy, the court noting the inequality of the employee's bargaining position); The Significance of Comparative Bargaining Power in the Law of Exculpation, 37 Col. L. Rev. 248, 249 (1937). 
Of the three theories of pensions-gratuity, unilateral contract, and deferred wage-either the unilateral contract or deferred wage theory allows recovery by the employee who has completed his term of service under the plan, while the gratuity theory recognizes no obligation whatsoever by the employer. In the earlier period before retirement, the unilateral contract theory is similar in effect to the gratuity theory. The deferred wage theory, on the other hand, while preserving the emphasis which the unilateral contract theory places upon continuity of service, affords recovery at all stages to the employee who has been promised a pension for remaining with his employer as long as he is able to do so.

\section{THE SINGLE RENTAL AS A "TRADE OR BUSINESS" UNDER THE INTERNAI REVENUE CODE}

The question of whether a taxpayer who owns and rents a single piece of real property is engaged in a "trade or business" has produced two adverse lines of authority highlighted by a recent conflict between circuits. One line of authority ${ }^{1}$ indicates that bare ownership of rented property is not a trade or business; that the trade or business status results from some degree of activity carried on by the taxpayer in operating and managing the property. The other view ${ }^{2}$ holds that the trade or business status results from a mere renting of the property, without inquiry into the extent of the taxpayer's rental activities. It is the purpose of this comment to compare these opposing views, examine the historical reasons for the conflict, and suggest a possible solution.

This issue-whether such rental activities constitute a trade or businesshas significance in the application of several sections ${ }^{3}$ of the Internal Revenue Code of $1954 .{ }^{4}$ Usually, but not always, it is to the taxpayer's advantage to be in a trade or business.

\footnotetext{
1 The second circuit (Grier v. United States, 218 F. 2d 603 [C.A. 2d, 1955], discussed at page 119 infra) and sixth circuit (Fackler v. Comm'r, 133 F. 2d 509 [C.A. 6th, 1943], discussed at page 113 infra).

${ }^{2}$ The Tax Court (John D. Fackler, 45 B.T.A. 708 [1941], discussed at page 113 infra, and Leland Hazard, 7 T.C. 372 [1946], discussed at page 117 infra) and the seventh circuit (Reiner v. United States, 222 F. 2d 770 [C.A. 7th, 1955], discussed at page 119 infra).

"The meaning of the words "trade or business" as used in some sections is not significant for the "small" landlord. Operating expenses and depreciation are deductible if the rental operation is either a "trade or business" (expenses $\$ 162$; depreciation $\$ 167$ ) or "production of income" (expenses $\S 212$; depreciation $\$ 167$ ). This may be compared to the provision on losses $(\$ 165)$, which are deductible if sustained in either a "trade or business" or a "transaction entered into for profit." In each instance the alternative category is easier to reach so litigation usually centers about it and doesn't reach the trade or business question. For this taxpayer the bad debts provision (Int. Rev. Code $\$ 166$ ) is also of little concern.
}

"Title 26 U.S.C.A. (1955), hereafter referred to as "the Code." 